University of Montana

ScholarWorks at University of Montana

Numerical Terradynamic Simulation Group

Publications

Numerical Terradynamic Simulation Group

6-1981

\title{
Transpiration From 100-yr-old Lodgepole Pine Forests Estimated with Whole-Tree Potometers
}

D. H. Knight

University of Montana, Missoula

T. H. Fahey

University of Montana, Missoula

Steven W. Running

University of Montana - Missoula

A. T. Harrison

University of Nebraska - Lincoln

L. L. Wallace

University of Oklahoma Norman Campus

Follow this and additional works at: https://scholarworks.umt.edu/ntsg_pubs

Let us know how access to this document benefits you.

\section{Recommended Citation}

Knight, D. H., Fahey, T. J., Running, S. W., Harrison, A. T. and Wallace, L. L. (1981), Transpiration From 100-yr-old Lodgepole Pine Forests Estimated with Whole-Tree Potometers. Ecology, 62: 717-726. doi:10.2307/1937740

This Article is brought to you for free and open access by the Numerical Terradynamic Simulation Group at ScholarWorks at University of Montana. It has been accepted for inclusion in Numerical Terradynamic Simulation Group Publications by an authorized administrator of ScholarWorks at University of Montana. For more information, please contact scholarworks@mso.umt.edu. 


\title{
TRANSPIRATION FROM 100-YR-OLD LODGEPOLE PINE FORESTS ESTIMATED WITH WHOLE-TREE POTOMETERS ${ }^{1}$
}

\author{
D. H. Knight, T. J. Fahey, S. W. Running, ${ }^{2}$ \\ A. T. HARrison, ${ }^{3}$ AND L. L. WALlaCE \\ Department of Botany, University of Wyoming, Laramie, Wyoming 82071 USA
}

\begin{abstract}
Whole-tree potometers were used to estimate transpiration from two contrasting stands of 100-yr-old lodgepole pine (Pinus contorta Dougl. var. latifolia Engelm.) forest growing on the same site in southeastern Wyoming. Although one stand had nearly seven times as many trees per hectare and $29 \%$ less biomass, both stands had nearly identical leaf area indices (7.3 and 7.1) and clear-day transpiration rates $(3.3$ and $3.4 \mathrm{~mm} / \mathrm{d}$ ). Individual tree basal area and maximum observed 24-h uptake were highly correlated, with the largest trees (20-26 cm dbh) transpiring $40-44 \mathrm{~L}$ on clear days in early summer. Maximum observed hourly uptake for the larger trees was 2.5-3.5 L, with total nighttime uptake being about $12 \%$ of 24 -h uptake. On overcast days potometer uptake was reduced by $30-44 \%$; during rainy periods uptake was reduced to nearly zero. The results are compared to data obtained with different methods by other investigators, with the conclusion that whole-tree potometers can be a useful tool for studies on tree water relations and for estimating short-term forest transpiration when leaf water potential is not limiting leaf conductance.
\end{abstract}

Key words: biomass; coniferous forest; leaf area; Pinus contorta; Rocky Mountains; transpiration; Wyoming.

\section{INTRODUCTION}

Transpiration affects various ecosystem characteristics. For example, cooling of soil, air, and plant tissues occurs when incoming energy is dissipated as latent heat of vaporization, and the rate of nutrient loss may be reduced if a large portion of incoming precipitation is diverted from deep percolation to the transpiration pathway. When timber harvest occurs the amount of water moving through the transpiration pathway is greatly reduced for a time, thereby increasing streamflow and the probability that nutrients will be leached from the system. More water is also available for erosion. Clearly, the environmental impact of some land management practices often occurs because the rate of transpiration and/or evapotranspiration has been affected. Despite the ecological importance of transpiration, this process is rarely measured in the field. In this paper we report on our experience using whole-tree potometers (Ladefoged 1960, 1963) for estimating transpiration in two 100-yr-old lodgepole pine forests (Pinus contorta Dougl. var. latifolia Engelm.) of contrasting structure.

A variety of techniques have been used for estimating evapotranspiration (Rutter 1968, Kramer and Kozlowski 1979). Some are empirical (Thornthwaite 1948), while others based on the Bowen ratio or Penman-Monteith equations are more theoretical (Mon-

\footnotetext{
${ }^{2}$ Manuscript received 14 January 1980; revised 11 July 1980; accepted 11 July 1980.

${ }^{2}$ Present address: School of Forestry, University of Montana, Missoula, Montana 59812 USA.

${ }^{3}$ Present address: Division of Life Sciences, University of Nebraska, Lincoln, Nebraska 68588.

${ }^{4}$ Present address: Department of Botany and Microbiology, University of Oklahoma, Norman, Oklahoma 73069 USA.
}

teith 1964, Van Bavel 1966, Rutter 1968, Tanner 1968). These approaches rely heavily on meteorological measurements. An alternative is to use watersheds, where the difference between net precipitation and streamflow is considered as an estimate of evapotranspiration. Through the study of small watersheds it has been possible to estimate the effect of vegetation structure on water and nutrient movement (Likens et al. 1977). The watershed approach has the drawback, however, of being applicable only to watersheds with an impervious substrate (no groundwater seepage) and lumping together a purely physical process (evaporation) with transpiration which is biologically controlled. Also, some questions about ecosystem function are better answered using single, homogeneous stands rather than watersheds as the basic unit of study. A more direct estimate of transpiration then becomes necessary because calculating the difference between precipitation and deep seepage is beset with problems for a single stand, primarily because percolation is so difficult to quantify. Monitoring soil water depletion with a neutron probe has been used to estimate evapotranspiration from single stands (Johnston 1975); however, this method cannot be used for estimating transpiration from coniferous forests during the snowmelt period because of constant soil moisture recharge and, as with watersheds, evaporation is not separated from transpiration.

Another approach is to estimate transpiration for individual trees of different sizes, or on a leaf area basis, and then to extrapolate to the whole stand using data on vegetation structure. A useful method for individual trees has been to monitor the velocity of a heat pulse applied to the transpiration stream (Ladefoged 1963, Doley and Grieve 1966, Swanson 1967, 
1972), but this method provides only relative rates for short periods and the uneven flow of water across the bole cross-section presents problems of calibration. The cut-branch and gas-exchange methods provide quantitative data on a leaf area basis, but the task of extrapolating to the whole tree and then to the whole forest canopy presents problems (Kramer and Kozlowski 1979). Transparent gas exchange tents have been placed over entire trees (Rutter 1968), with considerable logistical problems associated with constructing the tent and maintaining near ambient conditions inside. Kline et al. $(1970,1976)$ and Owston et al. (1972) have used tritiated water and ${ }^{32} \mathrm{P}$, respectively, to estimate whole-tree transpiration. This method holds considerable promise, though calibration is a problem here also. Still another option has been to build a weighing lysimeter under an intact tree (Fritschen et al. 1973, 1977). Though very useful for information on tree ecophysiology, it is prohibitively expensive to build such lysimeters under several trees of different sizes so that stand transpiration can be estimated.

The development of forest transpiration models based on tree ecophysiology has provided new opportunities for ecosystem analysis. Such models are usually constructed using micrometeorological and/or diffusion porometer data (Hinckley et al. 1975, Running et al. 1975, Sinclair et al. 1976, Waring and Running 1976, Tan et al. 1978, Luxmoore et al. 1978). While these porometer-based models provide the most promise for estimating stand transpiration, the need to extrapolate from leaf-level measurements to the whole canopy introduces uncertainty into the results. We felt that whole-tree potometers might serve to provide a more direct transpiration measurement for an entire tree, thereby providing a tool for model validation. A number of problems were encountered, but the method has provided information on the water relations of lodgepole pine as well as some reasonable estimates of stand transpiration under certain conditions. The method has the advantage of circumventing the problems of extrapolating from branches to the whole crown by providing data on the crown in its natural position. The effect of sapwood recharge and the severing of root resistance is examined.

\section{Study Area and Methods}

Most of the data were collected in three stands of lodgepole pine forest located between 2800 and 2900 $\mathrm{m}$ elevation in the Medicine Bow Mountains of southeastern Wyoming. As is typical of the distribution of lodgepole pine in the Rocky Mountains, the growing season is short, cool, and dry, with $60-70 \%$ of the total annual precipitation $(60 \mathrm{~cm})$ usually coming as snowfall. Most of the summer rains are $<1.3 \mathrm{~cm}$ and are totally intercepted by the canopy and forest floor litter (Reynolds and Knight 1973). Minimum air temperatures during the summer are usually below $4^{\circ} \mathrm{C}$ (at night), with maximum temperatures averaging $20-23^{\circ}$.

Midday relative humidity typically ranges from 15 to $25 \%$, except during thundershowers or on overcast days. The three stands were located on deep (>2 m), sandy-loam soils characterized by an abundance of stones and boulders. Additional data for evaluating potometer cut-effect were obtained in a fourth stand of lodgepole pine at the Fraser Experimental Forest $(2700 \mathrm{~m})$, maintained by the United States Forest Service in the Rocky Mountains of north-central Colorado. Climatic conditions at Fraser are similar to the stands in Wyoming (about $175 \mathrm{~km}$ to the north).

\section{The whole-tree potometer method}

The potometers were set up by first securing a tree to a large tripod. We used two types of tripods, one made from three logs long enough to be attached at the fulcrum by rope to a point on the tree well above the center of gravity, and the other made from three shorter aluminum legs which bolted to a cushioned aluminum collar on the trunk at about $2 \mathrm{~m}$ above the ground. In the former case the tree was suspended from above after being cut, whereas the aluminum tripod supported the tree from below. Guy cables were attached to the upper trunk to prevent the tree and aluminum tripod from tipping. Both tripods functioned satisfactorily, with the aluminum basal tripod being much easier to use on larger trees and the suspension tripod being easier with smaller trees.

After securing the tree to a tripod, the tree was cut and placed in a reservoir of water from which water loss (due to uptake) could be monitored. We used two cutting methods. With suspended trees, a temporary reservoir of water was established around the base of the tree, the bole then being cut underwater with a hand saw to avoid breaking the water column. The cut end of the tree was then placed in a plastic bag full of water while the tree was swung out and placed in the permanent reservoir (in our case a $1 \mathrm{~m}$ high plastic container with a $0.4 \mathrm{~m}$ diameter). When using the aluminum basal tripod the tree was cut twice near the base with a chainsaw, removing a $30-\mathrm{cm}$ section of the trunk near the ground. The tree then could be placed in a reservoir filled with water, where the trunk was cut again under water (about $30-40 \mathrm{~cm}$ up from the second cut) to re-establish an unbroken water column in the xylem. In either case, a plastic sheet was wrapped securely around the tree and reservoir to prevent direct evaporation from the reservoir. The reservoir was usually refilled at dawn and every $3 \mathrm{~h}$ during the day, the amount of water added each time being recorded as uptake. The extent to which potometer uptake is equal to transpiration will be discussed. As found by Roberts (1977), differences in uptake in relation to the two methods of cutting could not be detected. A total of 51 potometers were observed (ranging in size from 2 to $26 \mathrm{~cm} \mathrm{dbh}$ ) during a three-summer period (late May-August of each year), 
20 in a dense "doghair" stand of lodgepole pine (14 640 trees/ha) and 31 in two average stands $(\approx 2000$ trees/ha).

Establishing whole-tree potometers of trees $>30 \mathrm{~cm}$ dbh would be difficult. For trees $<30 \mathrm{~cm}$ dbh we had little difficulty establishing the potometer within $1 \mathrm{~h}$ once the tripod was secured to the tree. Usually we would set up 2-4 trees on the same day, monitoring each for uptake during a 2-3 d period, after which the potometers would be either terminated or recut under water. We observed a slowing of uptake after 2-3 d, due apparently to the plugging of tracheids by algae, bacteria, resin, and particulate matter. This material could be removed by recutting the bole a few centimetres higher, after which uptake occurred again at expected rates.

\section{Evaluating cut effect}

We anticipated that the transpiration rate would increase due to the elimination of root and soil resistance and the unlimited water supply which we provided in the reservoir. Various measurements were taken to determine if this did occur. First, base xylem pressure potential was determined for nearly every potometer the morning (predawn) before the cut and the morning after, using a Scholander pressure chamber (Scholander et al. 1965). This measurement indicated whether a significant change in tree water status occurred as a result of root excision and the provision of reservoir water. Secondly, leaf conductance ( $k_{l}$, centimetres per second) was measured just before and within an hour after 16 of the potometers were cut, using an aspirated diffusion porometer (Turner et al. 1969). These data provided an indication of whether or not transpiration rate changed. In addition to the potometers, the above measurements were taken also on some nearby intact trees of about the same size. Third, on 13 of the potometers we determined change in wood moisture content (\% dry mass) before and $24 \mathrm{~h}$ after cutting by extracting cores from the trunk with an increment corer. The cores were extracted at dawn, wrapped immediately in plastic film, and returned to the lab for drying.

Our fourth evaluation of cut-effect was done on 14 potometers cut at the Fraser Experimental Forest. A null balance diffusion porometer (Beardsell et al. 1972) was used for intact $k_{l}$ measurements before and after cutting the potometer tree, three branches being chosen on each tree (on N, SE, and SW aspects, respectively, at about mid-crown) with 3-4 twigs on each branch being measured. Both sun and shade leaves were monitored. At the end of testing a given potometer, the twigs were clipped and the leaf area (all surfaces) measured geometrically. Total leaf surface area in the cuvette was usually $75-125 \mathrm{~cm}^{2}$ (30-40 fascicles). To estimate leaf water potential $\left(\psi_{l}\right)$, pressure chamber measurements were made on individual fascicles.

The sampling schedule for the Fraser trees was as follows. Predawn leaf water potential $\left(B \psi_{l}\right)$ measurements on both the study tree and a control tree were taken the night before cutting the tree. After sunrise, $k_{l}$ and $\psi_{l}$ were measured on both trees at about 0730 and 1000 Mountain Standard Time (MST), after which the tree was cut and placed in the potometer reservoir. For an hour after the cut, $\psi_{l}$ was measured at 10 -min intervals to assess the recovery rate of the tree water system. During the afternoon potometer uptake was monitored at 3-h intervals and three more sets of $\psi_{l}$ and $k_{l}$ data were recorded. After dark the potometer reservoir was refilled so that overnight uptake in the absence of transpiration could be determined. The reservoir was refilled shortly after dawn the following morning (day 2) and two additional sets of $\psi_{l}$ and $k_{l}$ data were taken (at 0730 and 1000 MST).

For comparison, whole crown transpiration was estimated using a water vapor diffusion equation. First, transpiration flux density $(T F D)$ was calculated,

$$
T F D=A B S H D \times k_{l}
$$

where $A B S H D$ is absolute humidity deficit (micrograms per cubic centimetre) calculated for each hour (see below for data source), $k_{l}$ is the average of the 9 to $12 k_{l}$ measurements for the tree in question, and the units for $T F D$ are micrograms per square centimetre of leaf area per second. Hourly transpiration rates (TRANS) for the whole tree were calculated,

$$
T R A N S=T F D \times L A \times 3600 \mathrm{~s} / \mathrm{h}
$$

with TRANS in micrograms per hour and $L A$ being total leaf area in square centimetres.

\section{Biomass and leaf area estimation}

At the termination of readings for each potometer the trees were lowered to the ground. Branches were cut off at the bole and weighed in the field, with weighed subsamples then being taken back to the laboratory for determination of moisture content. After drying the leaves were easily stripped from the branches, weighed, and expressed as a percentage of total branch mass. The entire bole was also weighed in the field, with small sections being returned to the lab for drying. All field values were converted to dry masses. Bole sapwood volume was estimated geometrically using sapwood cross-sectional area measurements from the sections taken at different heights. Leaf area was estimated after measuring (with a micrometer) surface area (all surfaces) per gram of leaf (fresh mass). Total leaf biomass for the potometer was multiplied by this factor to obtain total tree leaf area. Since potometers of various sizes were 


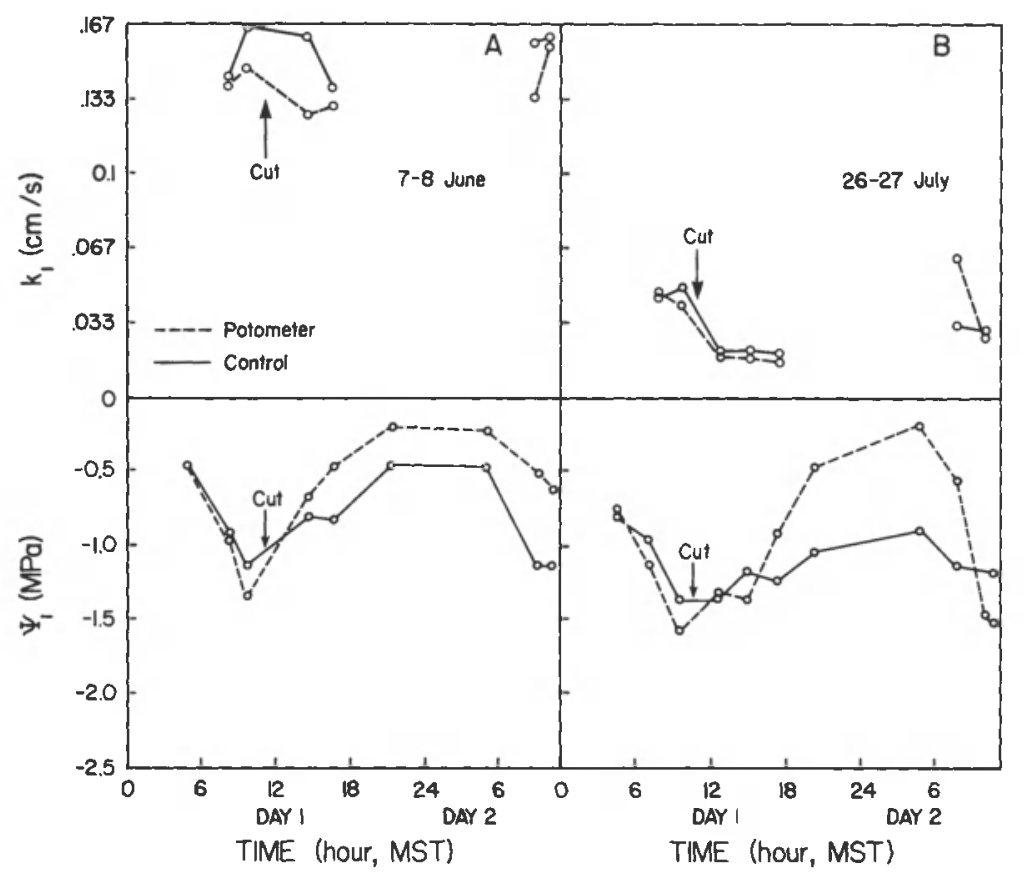

FIG. 2. Data for a potometer and an intact control tree, of the same size and in a similar microclimate, that illustrate the effect of removing soil and root resistance on leaf water potential $\left(\psi_{l}\right)$ and leaf conductance $\left(k_{1}\right)$ during: $(A)$ a period with no soil moisture stress (7-8 June), and (B) a period with moisture stress (26-27 July). MST = Mountain Standard Time. See text for interpretation.

Hinckley et al. 1978). For our study the only factor which could be affected by cutting is $\psi_{l}$ since the micrometeorological conditions around the tree are not changed. For the 49 potometers measured, predawn $\psi_{l}$ always increased from the morning before cutting to the morning after. This recovery ranged from 0.1 to over $1.1 \mathrm{MPa}$, but an increased $k_{l}$ was observed only if $\psi_{l}$ had been the controlling factor of $k_{l}$ before the cut. To illustrate, the data for an early June (7 June) potometer are presented in Fig. 2A. This tree was cut at 1100 , with predawn $\psi_{l}$ increasing by 0.24 MPa by the next day. Soil water could not have been limiting at this time, just after snowmelt, so the recovery reflected only the removal of root resistance and the availability of a free water source. Leaf conductance was at maximum levels before and after the cut.

In contrast, Fig. 2B illustrates the response of a tree cut later in the summer (26 July) when depleted soil water produced $\psi_{l}$ values that limited $k_{l}$. Predawn $\psi_{l}$ recovered from -0.75 to $-0.21 \mathrm{MPa}$ the day after cutting. Running $(1976,1980 b)$ found a high correlation between predawn $\psi_{l}$ and morning $k_{l}$ at these levels of $\psi_{l}$. As his analysis predicts, the recovery of $\psi_{l}$ produced a higher $k_{l}$ the morning after cutting (from 0.47 to $0.63 \mathrm{~cm} / \mathrm{s}$ ).

Therefore, the cut-effect leads to a change in transpiration only if $\psi_{l}$ is controlling $k_{l}$. When soil water is not limiting, a change in $\psi_{l}$ does not affect $k_{l}$. Fetch- er (1976) and Running (1980b) found that soil water depletion in our area did not cause $\psi_{l}$ levels that would reduce $k_{l}$ until mid-July or later during years of normal summer precipitation, and consequently it appears that whole-tree potometers would be dependable only before this time.

\section{Individual tree uptake}

Diurnal patterns of uptake were as expected, with maximum rates occurring at midday on clear days and the largest trees transpiring most rapidly (Fig. 3). Uptake at night $(0.1-0.65 \mathrm{~L} / \mathrm{h})$ was about $10 \%$ higher than calculated using Eq. 2, and can be attributed primarily to sapwood recharge, since both nocturnal evaporative demand and cuticular transpiration from the sclerophyllous needles are low (nocturnal $k_{l}$ was observed to be $0.01 \mathrm{~cm} / \mathrm{s}$, with a maximum daytime $k_{l}$ being $0.20 \mathrm{~cm} / \mathrm{s})$. Whole-crown conductance $\left(k_{c}\right)$ of the potometers was generally highest in midmorning and declined during the day (Fig. 4), a pattern which was also observed using the diffusion porometer on intact trees. A notable exception was one understory tree where $k_{c}$ increased during the day, perhaps because of increasing light exposure.

Maximum observed hourly uptake rates on clear days were plotted against tree size to further evaluate potometer performance (Fig. 5). As observed by Kline et al. (1976), we found a close relationship between sapwood area and transpiration rate $\left(r^{2}=0.90\right)$; how- 


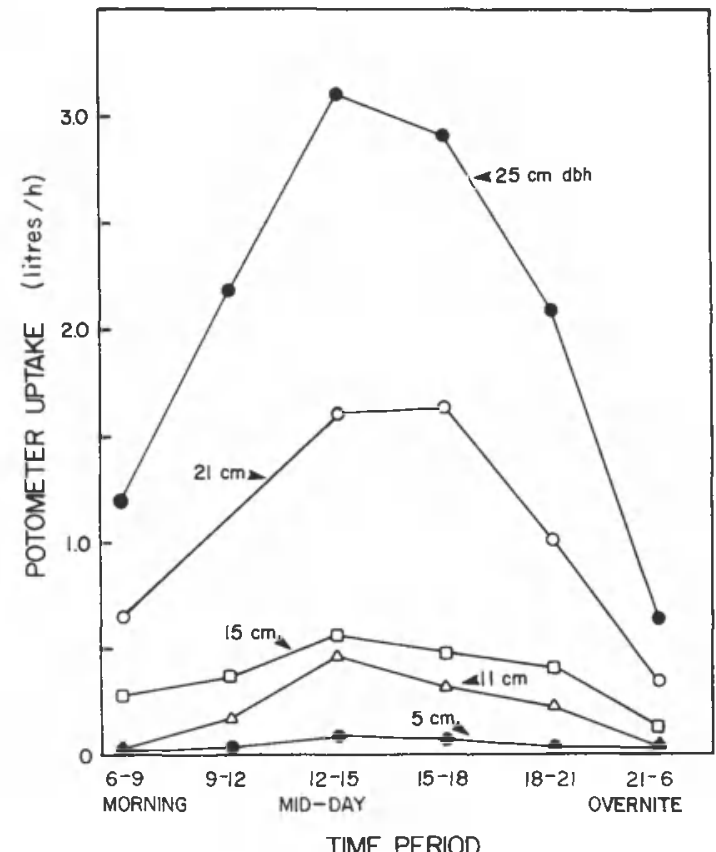

Fig. 3. Diurnal patterns of potometer uptake (an estimate of actual transpiration) for trees of different sizes.

ever, the $r^{2}$ with sapwood area was no higher than for basal area. As the trees grow larger, sapwood area may retain a closer correlation than basal area with transpiration. The maximum observed transpiration was $3.5 \mathrm{~L} / \mathrm{h}$ for a $24 \mathrm{~cm}$ dbh tree $\left(452 \mathrm{~cm}^{2}\right.$ basal area). The uptake of smaller trees was much less, due in part to the much smaller leaf area but also to the more shaded environment of the small-tree crown. Midday hourly uptake was reduced by about $43 \%\left(s_{\bar{x}}=2.6\right)$ during periods of overcast skies, and to nearly zero when overcast and raining (an indication that sapwood recharge had occurred).

\section{Stand transpiration}

A primary motivation for our potometer research was to develop a means of studying the effect of forest stand structure on water movement (including transpiration). Although often viewed as very homogeneous, lodgepole pine forests may or may not be evenaged and stands of the same age and origin may be very dense or very open. In our Dry Park study area, where most of the potometer work was done, a very dense "doghair" stand occurs immediately adjacent to a more typical open stand. Both originated $\approx 100 \mathrm{yr}$ ago, following the same extensive fire, and both are found on a flat plateau with identical soil profiles. Although the stands are very different in tree density and total tree biomass, the leaf area index $(L A I)$ is $\approx 7$ in both. (Table 1). We anticipated similar transpiration rates also, but desired a method of providing a quantitative estimate. We pro-

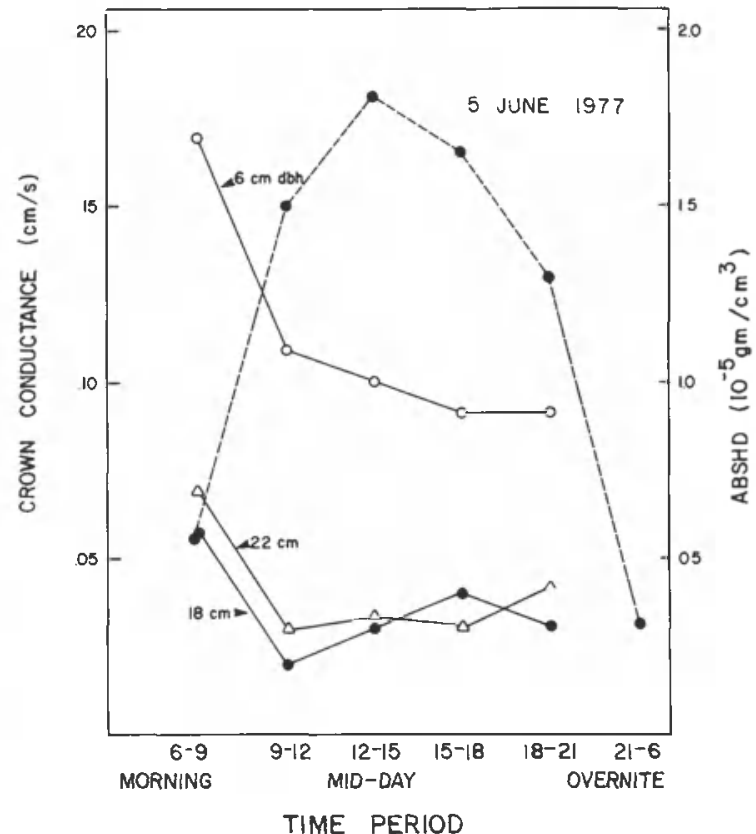

FIG. 4. Representative diurnal patterns of potometer crown conductance $(\mathrm{cm} / \mathrm{s})$ and $A B S H D\left(\mathrm{~g} / \mathrm{cm}^{3} \times 10^{-5}\right)$ early in summer ( 5 June 1977) before soil moisture becomes limiting. Currently we have no explanation for why the smaller trees have higher $k_{l}$ values. $A B S H D$ (absolute humidity deficit) - . . .

ceeded as follows: First, hourly uptake rates were summed for a 24 -h period to estimate daily transpiration. We assumed that nighttime uptake represented the recharge of a sapwood water deficit created by transpiration during the previous day, and therefore nighttime uptake is counted as actual transpiration. A close relationship was found between tree basal area and maximum-observed 24-h uptake (Fig. 6), with the largest tree $(26 \mathrm{~cm} \mathrm{dbh})$ transpiring $44 \mathrm{~L}$ on clear days in late May. The data for all potometers were combined for Fig. 6, since no statistically significant differences between stands were observed. Although the 51 potometers were cut at different times of the summer (between 18 May and 23 August), the regression of tree basal area on maximum uptake had an $r^{2}$ of 0.89. Evaporative demand undoubtedly varied from one clear day to the next, but more stomatal control on the warmest days may have compensated for greater humidity deficits.

After calculating the regression between tree basal area and maximum 24-h uptake, a known area (150$600 \mathrm{~m}^{2}$ ) was delineated in each of the Dry Park stands, with the basal area of each tree then being measured. The daily transpiration of each tree was then estimated from the regression equation, all tree estimates were summed, and the total was divided by stand area to give a stand estimate in litres per square metre per day. This value was converted to centimetres per day 


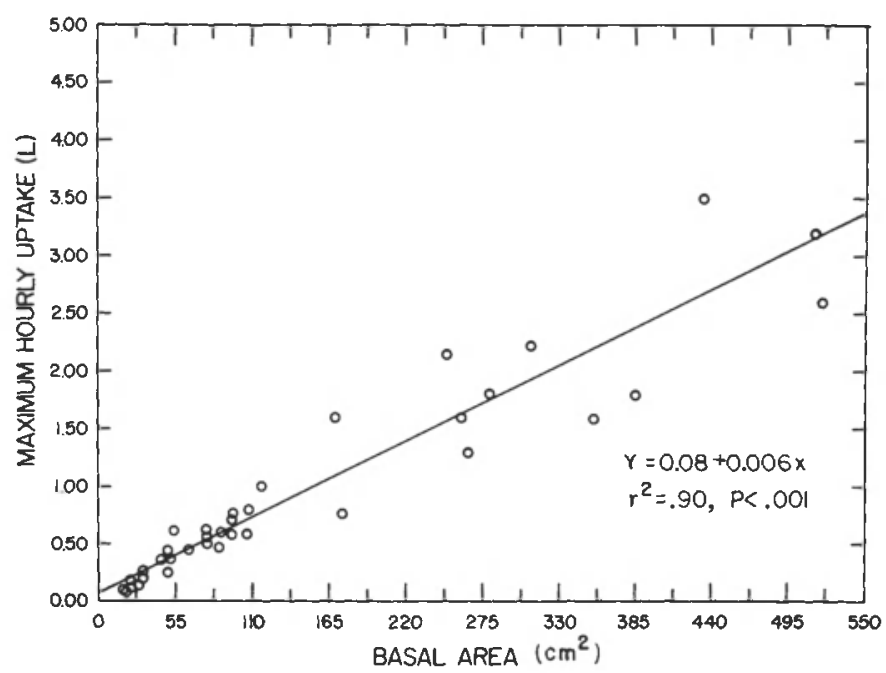

FIG. 5. Regression of maximum-observed hourly potometer uptake on clear days against potometer basal area.

and was also divided by $L A I$ to express transpiration on a leaf area basis, i.e., transpiration flux density (TFD).

As anticipated, the maximum daily transpiration of the two stands was very similar $(0.34$ and $0.33 \mathrm{~cm}$, Table 1). Eight potometers were functioning on both clear and overcast days, permitting the estimation of transpiration on days of contrasting atmospheric conditions. A $50 \%$ reduction in $A B S H D$ (and corresponding changes in $k_{l}$ ) caused $30-44 \%$ less daily uptake by individual trees, a reduction which is probably appropriate for our stand estimates as well.

The observation that two forest stands of contrasting structure have the same $L A I$ and transpiration rates is intriguing. Moir and Francis (1972) found lodgepole pine forest $L A I$ to range from 4.5 to 14.0 in nearby Colorado, but they studied stands on different sites. Our two stands were adjacent, on the same site, and had the same history. The fact that their $L A I$ was very similar is consistent with Grier and Running's (1977) observation that $L A I$ is highly correlated to site water balance in water-limited stands.
As they had similar LAI's, it might be expected that transpiration rates would also be similar in the two stands. Certainly canopy structure is known to affect gaseous diffusion (Jarvis et al. 1976), but in our situation air movement is probably sufficient to cause thorough mixing. If canopy structure had such an influence the regressions of maximum hourly transpiration against basal area for the two stands should have been different. The results further emphasize that water yield from a watershed or water loss from a stand is more dependent on stand leaf area than tree size or stand biomass. The harvest of dense stands of small trees may contribute to stream flow as much as the harvest of more open stands with much larger trees.

Although the two stands appear to be transpiring at about the same rate, the quantitative estimates are still open to question. Uptake alone suggests that maximum daily transpiration occurs at the rate of about 3.3 $\mathrm{L} \cdot \mathrm{m}^{-2} \cdot \mathrm{d}^{-1}$, an estimate close to estimates obtained in a similar manner by Ladefoged (1963) for beech and Norway spruce (4.0 and 3.8, respectively), Our anal-

TABle 1. Data on stand structure and daily transpiration for the two contrasting stands of lodgepole pine forest at Dry Park.

\begin{tabular}{|c|c|c|c|}
\hline Feature & Units & Dense stand & Average stand \\
\hline Stand age & years & 100 & 100 \\
\hline Tree density & trees/ha & 14640 & 2217 \\
\hline Stand basal area & $\mathrm{m}^{2} / \mathrm{ha}$ & 50 & 42 \\
\hline Canopy height & $\mathbf{m}$ & 6 & 12 \\
\hline Tree biomass (aboveground) & $\mathrm{kg} / \mathrm{ha}$ & 101423 & 142263 \\
\hline Leaf biomass & $\mathrm{kg} / \mathrm{ha}$ & 8416 & 9707 \\
\hline Surface area per gram fresh leaf mass & $\mathrm{cm}^{2} / \mathrm{g}$ & 84 & 75 \\
\hline Leaf area index $(L A I)$ & $\mathrm{m}^{2} / \mathrm{m}^{2}$ & 7.1 & 7.3 \\
\hline \multirow[t]{2}{*}{ Clear day transpiration } & $\mathrm{L} \cdot \mathrm{m}^{-2} \cdot \mathrm{d}^{-1}$ & 3.4 & 3.3 \\
\hline & $\mathrm{cm} / \mathrm{d}$ & 0.34 & 0.33 \\
\hline \multirow[t]{2}{*}{ Clear day transpiration flux density (TFD) } & $\mathrm{L} \cdot \mathrm{m}^{-2}$ leaf area $\cdot \mathrm{d}^{-1}$ & 0.479 & 0.452 \\
\hline & $\mathrm{mg} \cdot \mathrm{cm}^{-2}$ leaf area $\mathrm{d}^{-1}$ & 47.9 & 45.2 \\
\hline
\end{tabular}




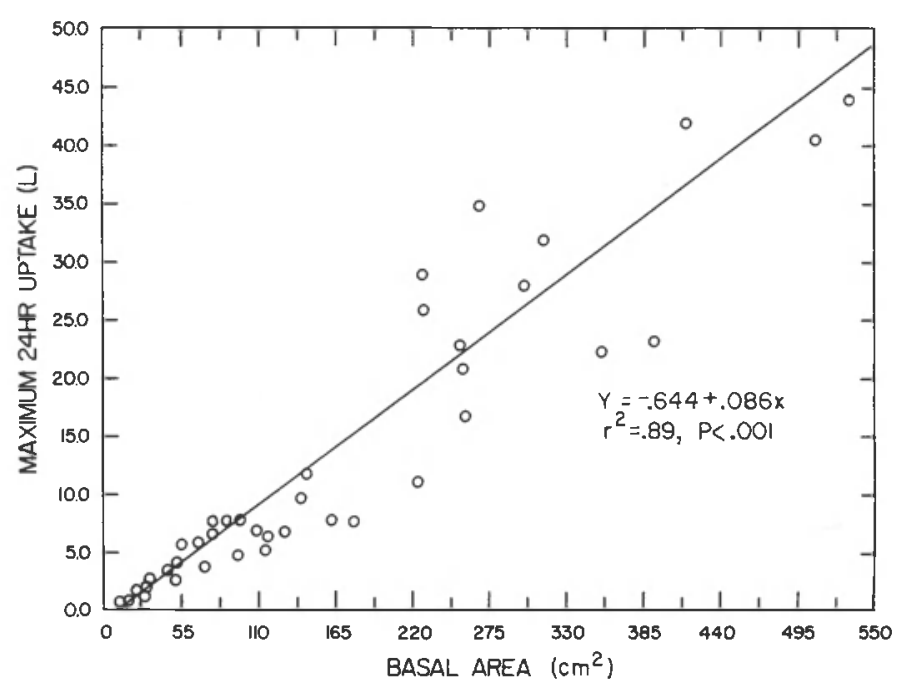

Fig. 6. Regression of maximum-observed 24-h potometer uptake on potometer basal area.

ysis of cut-effect suggests that our uncorrected potometer estimates may be about $125 \%$ of the actual rate; however, as noted previously, transpiration from large trees is difficult to measure with certainty by any available method. Some indirect evidence suggests that actual potometer uptake provides a good estimate under certain conditions. For example, the maximum hourly uptake that we observed for a $24-\mathrm{cm}$ tree is very close to the transpiration estimate of Owston et al. (1972) for a lodgepole pine tree of about the same size (3.5 and $3.9 \mathrm{~L} / \mathrm{h}$, respectively). A second line of evidence relates to the availability of energy for evaporating water from the stand. The evaporation of $3.3 \mathrm{~L} / \mathrm{m}^{2}$ would require about $35 \%$ of the net radiation at Dry Park on a clear day, a percentage which is actually below that commonly used for transpiration in some energy budgets (Rutter 1967). If anything, more energy might be available for transpiration, suggesting that indeed potometer uptake may provide a more accurate transpiration estimate than Eq. 2. Our daily stand transpiration estimate of $3.4 \mathrm{~mm} / \mathrm{d}$, based on uncorrected potometer uptake, is within the range reported by Rutter (1966) for forest transpiration (1-5 mm/d), and, when expressed on a leaf area basis $\left(\mathrm{cm}^{2}\right)$, our mean estimate $\left(46.6 \mathrm{mg} \cdot \mathrm{cm}^{-2} \cdot \mathrm{d}^{-1}\right)$ is very close to estimates reported by Caughey (1945) and Kramer (1969) for Pinus taeda $\mathrm{L}$. seedlings $\left(46.5\right.$ and $50.8 \mathrm{mg} \cdot \mathrm{cm}^{-2} \cdot \mathrm{d}^{-1}$, respectively). Transpiration estimates obtained at different places and times may be similar or different because of varying evaporative demand, but the comparisons do suggest that whole-tree potometers can provide reasonable estimates of hourly and daily transpiration.

Although our transpiration estimates seem reasonable, a principal deficiency must be emphasized. By necessity the potometer trees were cut on different days and at different times during the spring and summer. Each point on our regression between 24 -h transpiration and basal area (Fig. 6) was obtained on days with slightly different environmental conditions, though all are for clear sunny days. Therefore, our estimate is not for any particular day, but for an average clear day in June or early July before the trees come under water stress.

Partly because of late summer stomatal closure (Fetcher 1976, Running 1980b) we have not attempted to extrapolate to seasonal and annual transpiration estimates. Too many assumptions would be required. We know that nighttime frost inhibits spring transpiration (Fahey 1979) and that transpiration is reduced to nearly zero during rainstorms and by about $40 \%$ on overcast days, but other required information is still insufficient, e.g., length of the transpiration season, the depth of the functional rooting zone, and the effect of late summer soil moisture recharge. The prediction of long-term transpiration requires a model capable of integrating the combined effect of all relevant factors affecting evaporative demand and leaf conductance. Work is currently in progress toward this goal for lodgepole pine forest. Whole-tree potometers have been used for what appears to be their most significant value, i.e., as a method for: (1) studying the effect of atmospheric conditions on tree water relations (Running 1980c); (2) observing the effects of sapwood recharge and the severing of soil/root/bole resistances (Roberts 1977); and (3) for providing one additional means of judging the accuracy of short-term (hourly or daily) transpiration estimates made by a stand simulation model. Although accurate long-term estimates cannot be based on whole-tree potometer data alone, potometers can be used for comparing species or for comparing stands of different structure, 
and they provide an opportunity to estimate transpiration rather than evapotranspiration. More data on transpiration will be required as ecologists probe further into the biotic regulation of water and nutrient movement through ecosystems.

\section{ACKNOWLEDGMENTS}

We thank Russell Campbell, Steve Grossnickle, Clay Kyte, Marvin Maxell, John Pearson, Brant Rogers, William Romme, Richard Starr, and Don Young for their help with various aspects of this research. Douglas G. Fox and Ramona Wilson provided valuable logistical support, and Ned Fetcher, C. P. P. Reid and William K. Smith made helpful suggestions. This research has been supported by grants from the National Science Foundation; the Department of Interior, Office of Water Research and Technology; and the Wyoming Water Resources Research Institute. We gratefully acknowledge the provision of facilities at the Fraser Experimental Forest by the United States Forest Service Rocky Mountain Forest and Range Experiment Station.

\section{Literature Cited}

Beardsell, M. F., P. G. Jarvis, and B. Davidson. 1972. A null-balance diffusion porometer suitable for use with leaves of many shapes. Journal of Applied Ecology 9:677690.

Caughey, M. G. 1945. Water relations of pocosin or bog shrubs. Plant Physiology 20:671-689.

Doley, D., and B. J. Grieve. 1966. Measurement of sap-flow in a eucalypt by thermo-electric methods. Australian Forest Research 2:3-27.

Fahey, T. J. 1979. The effect of night frost on the transpiration of Pinus contorta ssp. latifolia. Oecologia Plantarum 14:483-490.

Fetcher, N. 1976. Patterns of leaf resistance to lodgepole pine transpiration in Wyoming. Ecology 57:339-345.

Fritschen, L. J., L. Cox, and R. Kinerson. 1973. A 28-meter Douglas fir in a weighing lysimeter. Forest Science 19:256261.

Fritschen, L. J., J. Hsia, and P. Doraiswamy. 1977. Evapotranspiration of a Douglas fir determined with a weighing lysimeter. Water Resources Research 13:145-148.

Grier, C. C., and S. W. Running. 1977. Leaf area of mature northwestern coniferous forests: relation to site water balance. Ecology 58:893-899.

Hinckley, T. M., M. O. Schroeder, J. E. Roberts, and D. N. Bruckerhoff. 1975. Effect of several environmental variables and xylem pressure potential on leaf surface resistance in white oak. Forest Science 21:201-211.

Hinckley, T. M., J. P. Lassoie, and S. W. Running. 1978. Temporal and spatial variations in the water status of forest trees. Forest Science Monograph Number 20, Society of American Foresters, Washington, D. C., USA.

Jarvis, P. G. 1976. The interpretation of the variations in leaf water potential and stomatal conductance found in canopies in the field. Philosophical Transactions of the Royal Society of London 273:593-610.

Jarvis, P. G., G. B. James, and J. J. Landsberg. 1976. Coniferous forest. Pages 171-240 in J. L. Monteith, editor. Vegetation and the atmosphere. Academic Press, New York, New York, USA.

Johnston, R. S. 1975. Soil water depletion by lodgepole pine on glacial till. Forest Service Research Note INT-199, Intermountain Forest and Range Experiment Station, Ogden, Utah, USA.

Kaufmann, M. R., and A. N. Eckard. 1977. A portable instrument for rapidly measuring conductance and transpiration of conifers and other species. Forest Science 23:227-237.
Kline, J. R., J. R. Martin, C. F. Jordan, and J. J. Koranda. 1970. Measurement of transpiration in tropical trees using tritiated water. Ecology 51:1068-1073.

Kline, J. R., K. L. Reed, R. H. Waring, and M. C. Stewart. 1976. Field measurement of transpiration in Douglas fir. Journal of Applied Ecology 13:273-282.

Kramer, P. J. 1969. Plant and soil water relationships: a modern synthesis. McGraw-Hill, New York, New York, USA.

Kramer, P. J., and T. T. Kozlowski. 1979. Physiology of woody plants. Academic Press, New York, New York, USA.

Ladefoged, K. 1960. A method for measuring the water consumption of larger intact trees. Physiologia Plantarum 13:648-658.

1963. Transpiration of forest trees in closed stands. Physiologia Plantarum 16:378-414.

Likens, G. E., F. H. Bormann, R. S. Pierce, J. S. Eaton, and N. M. Johnson. 1977. Biogeochemistry of a forested ecosystem. Springer-Verlag, New York, New York, USA.

Luxmoore, R. J., D. D. Huff, R. K. McConathy, and B. E. Dinger. 1978. Some measured and simulated plant water relations of yellow poplar. Forest Science 24:327-341.

Moir, W. H., and R. Francis. 1972. Biomass and surface area in three Pinus contorta plots in Colorado. Forest Science 18:41-45.

Monteith, J. L. 1964. Evaporation and environment. Symposium of the Society of Experimental Biology 19:205-234.

Owston, P. W., J. L. Smith, and H. G. Halverson. 1972. Seasonal water movement in tree stems. Forest Science 18:266-272.

Reynolds, J. F, , and D. H. Knight. 1973. The magnitude of snowmelt and rainfall interception by litter in lodgepole pine and spruce-fir forests in Wyoming. Northwest Science 47:50-60.

Roberts, J. 1977. The use of tree-cutting techniques in the study of water relations of mature Pinus sylvestris L. Journal of Experimental Botany 28:751-767.

Running, S. W. 1976. Environmental control of leaf water conductance in conifers. Canadian Journal of Forest Research 6:104-112.

1980 $\mathrm{a}$. Relating plant capacitance to the water relations of Pinus contorta. Forest Ecology and Management 2:237-252.

- 1980b. Environmental and physiological control of water flux through Pinus contorta. Canadian Journal of Forest Research 10:82-91.

$1980 \mathrm{c}$. Field estimates of root and xylem resistances in Pinus contoria using root excision. Journal of Experimental Botany 31:555-569.

Running, S. W., R. H. Waring, and R. A. Rydell. 1975. Physiological control of water flux in conifers: a computer simulation model. Oecologia (Berlin) 18:1-16.

Rutter, A. J. 1966. Studies in the water relations of Pinus sylvestris in plantation conditions. IV. Direct observations on the rates of transpiration, evaporation of intercepted water, and evaporation from the soil surface. Journal of Applied Ecology 3:393-405.

- 1967. An analysis of evaporation from a stand of Scots pine. Pages $403-417$ in W. E. Sopper and H. W. Lull, editors. Forest hydrology. Pergamon Press, Oxford, England.

—_. 1968. Water consumption by forests. Pages 23-76 in T. T. Kozlowski, editor. Water deficits and plant growth. Volume 2. Academic Press, New York, New York, USA

Scholander, P. F., H. T. Hammel, E. D. Bradstreet, and E. A. Hemmingsen. 1965. Sap pressure in vascular plants. Science 148:339-346.

Sinclair, T. R., C. E. Murphy, Jr., and K. R. Knoerr. 1976. Development and evaluation of simplified models for sim- 
ulating canopy photosynthesis and transpiration. Journal of Applied Ecology 13:813-829.

Swanson, R. H. 1967. Seasonal course of transpiration of lodgepole pine and Engelmann spruce. Pages 419-434 in W. E. Sopper and H. W. Lull, editors. Forest hydrology. Pergamon Press, Oxford, England.

1972. Water transpired by trees is indicated by heat pulse velocity. Agricultural Meteorology 10:277-281.

Tan, C. S., T. A. Black, and J. U. Nnyamah. 1978. A simple diffusion model of transpiration applied to a thinned Douglas fir stand. Ecology 59:1221-1229.

Tanner, C. B. 1968. Evaporation of water from plants and soil. Pages 73-106 in T. T. Kozlowski, editor. Water deficits and plant growth. Volume 1. Academic Press, New York, New York, USA.

Thornthwaite, C. W. 1948. An approach toward a rational classification of climate. Geographical Review 38:55-94.
Turner, N. C., F. C. C. Pedersen, and W. H. Wright. 1969. An aspirated diffusion porometer for field use. Special Bulletin Soils XXIX/200. Connecticut Agricultural Experiment Station, New Haven, Connecticut, USA.

Van Bavel, C. H. M. 1966. Potential evaporation: the combination concept and its experimental verification. Water Resources Research 2:455-467.

Waring, R. H., and S. W. Running. 1976. Water uptake, storage and transpiration by conifers. A physiological model. Pages 189-202 in O. L. Lange, E. D. Schulze, and L. Kappen, editors. Water and plant life: problems and modern approaches. Ecological Studies. Volume 19. SpringerVerlag, Berlin, West Germany.

Waring, R. H., and S. W. Running. 1978. Sapwood water storage: its contribution to transpiration and effect upon water conductance through the stems of old growth Douglas fir. Plant, Cell, and Environment 1:131-140. 